\title{
Investigating and Comparison the Ethical Reasoning Level of Nursing Students Aja University of Medical Sciences with Nurses Working in One of Their Affiliated Hospitals
}

Badri Gargari. R ${ }^{1}$
Mahmoodi. $\mathrm{F}^{2}$
*Soltani. $\mathrm{N}^{3}$
Laripour. $\mathrm{R}^{4}$
1- Ph.D., in Educational
Psychology, Professor,
Educational Science
Department, Faculty of
Educational Sciences and
Psychology, University of Tabriz,
Tabriz, Iran.
2- Ph.D., in Curriculum Studies,
Associate Professor,
Educational Science
Department, Faculty of
Educational sciences and
psychology, University of Tabriz,
Tabriz, Iran.
3- ('Corresponding Author)
Ph.D., Student in Educational
Psychology, Educational
Science Department, Faculty
of Educational Sciences and
Psychology, University of Tabriz,
Tabriz, Iran.
Email: n.soltani1362@gmail.com
4- Ph.D., in Medical Education,
Center for Educational Research
in Medical Sciences, Iran
University of Medical Sciences,
Tehran, Iran.

\begin{abstract}
Introduction: Nurses face numerous ethical challenges in their profession; the growth of ethical experiences along with knowledge of theory and clinical skills is an indispensable necessity.
\end{abstract}

Objective: The present study aimed to investigate and compare the ethical reasoning level of nursing students at AJA University of Medical Sciences with nurses working in one of their affiliated hospitals.

Materials and Methods: The descriptive -comparative study was performed on 70 nursing students and 68 nurses working selected by convenience sampling method. To collect data, the Nursing Dilemma Test (DNT) consisting of 6 scenarios was used. The data were analyzed using SPSS and descriptive and inferential statistics.

Results: The mean score of moral reasoning in nursing students and working nurses were $48.18 \pm 2.2$ and $42.91 \pm 3.1$, respectively. The results of the t-test with independent samples indicate that the moral reasoning scores of nursing students are significantly higher than working nurses $(\mathrm{P}=0.03)$.

Discussion and Conclusion: Taking actions to train ethical issues and improve the clinical environment is essential to enhance nurses' moral reasoning ability.

Keywords: Ethic, Ethical Reasoning, Kohlberg's Stages of Moral, Nurses, Nursing Students. 


\section{بررسى و مقايسه سطح استدلال اخلاقى دانشجويان يرستارى دانشكاه علوم يزشكى آجا با

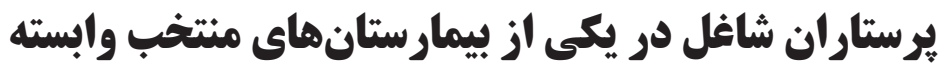

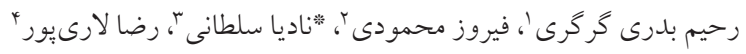

جكيده

مقدمه: يرستاران در حرفه خود با جالشهاى اخلاقى متعددى مواجه مىشوند، رشد تجارب اخلاقى در كنار دانش تئورى و مهارتهاى بالينى ضرورتى انكارنايذير است.

هدف: هدف از اين مطالعه، بررسى و مقايسه سطح استدلال اخلاقى دانشجويان دانشكاه علوم يزشكى آجا با يرستاران شاغل در يكى از بيمارستانهاى منتخب وابسته به آن است.

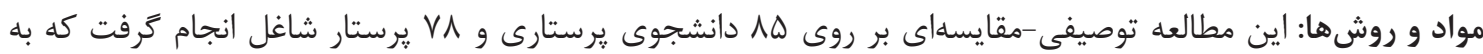
روش نمونهَيرى در دسترس انتخاب شدند. جهت جمعآورى دادها از يرسشنامه NDT) Nursing Dilemma Test) كه

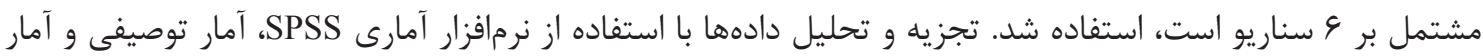

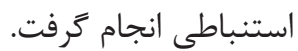

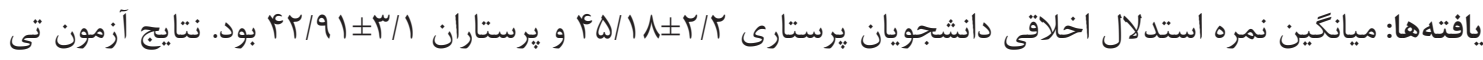

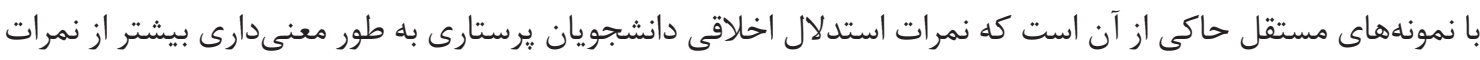

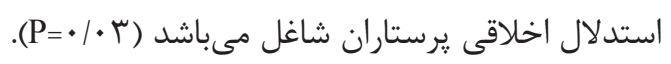

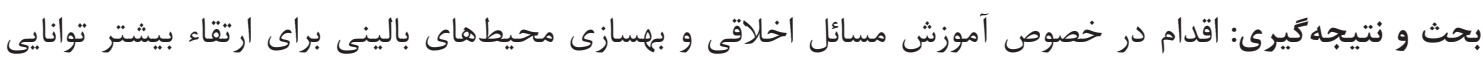
استدلال اخلاقى يرستاران، امرى ضرورى است.

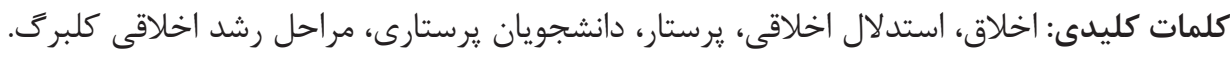

\begin{tabular}{|c|c|c|}
\hline เ & 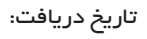 & 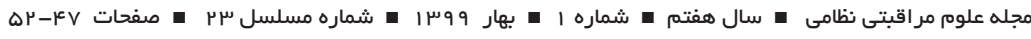 \\
\hline 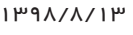 & ت تاريخ يذيرش: & \\
\hline I & 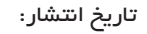 & \\
\hline
\end{tabular}

معمولى با مسائل اخلاقى بيشترى سروكار دارند و مسائل اخلاقى

مقدمه

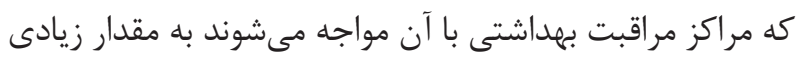

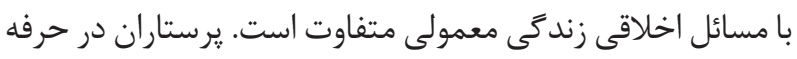

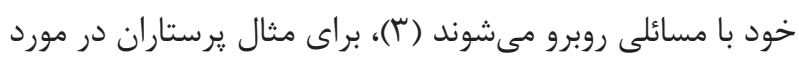

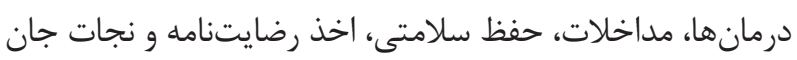

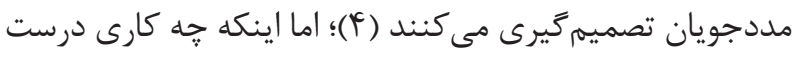

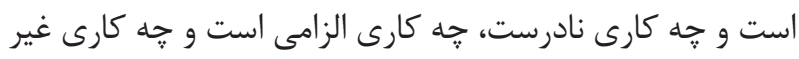

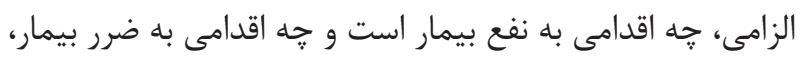

يكى از اساسىترين مباحث در عملكرد حرفهاى يرستاران، مسائل اخلاقى است. ماهيت برستارى به كَونهاى است كه بايد به اخلاقيات

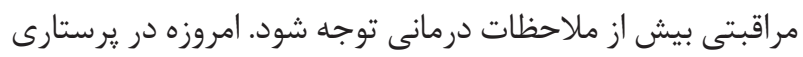

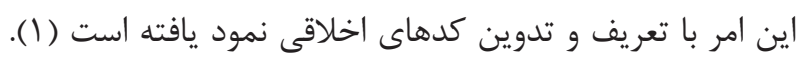

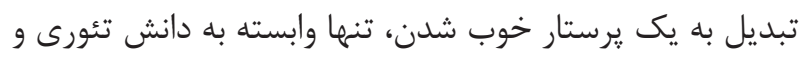

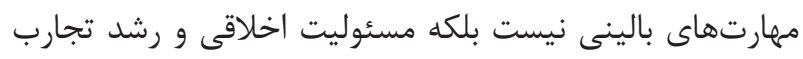

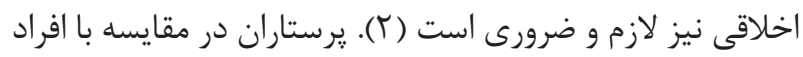

اـــ دكتراى روانشناسى تربيتى، كروه علوم تربيتى، دانشكده علوم تربيتى و روانشناسى، دانشكاه تبريز، تبريز، ايران.

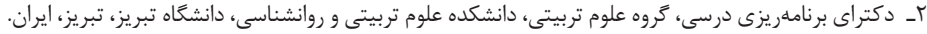

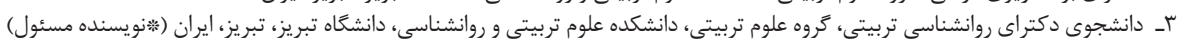

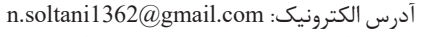


برَزيده است و شامل احترام به عدالت و انصاف و تساوى حقوق

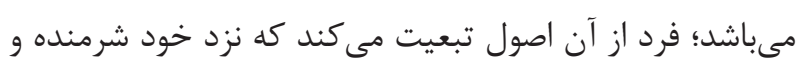

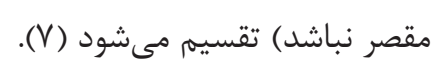

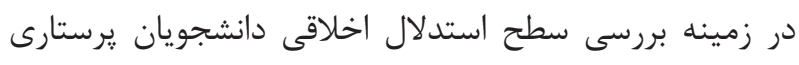

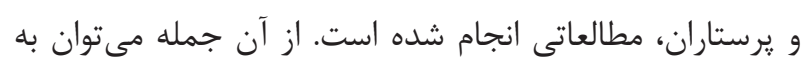

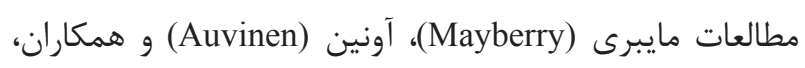

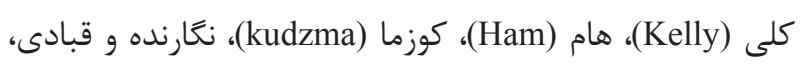

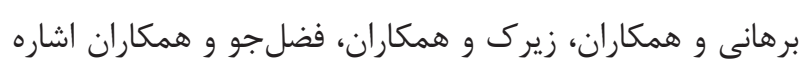

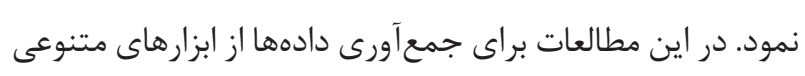

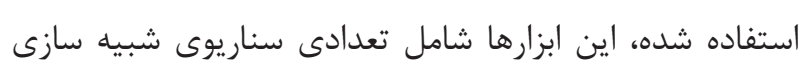

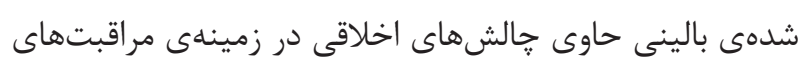
يرستارى هستند كه نحوهى ياسخ شركت كنند مان به موقعيتهاى

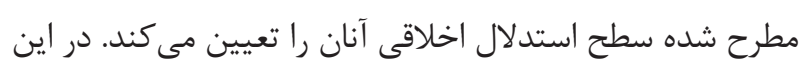

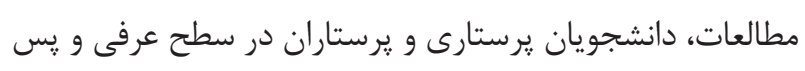

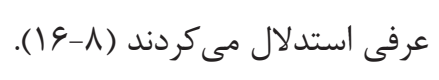

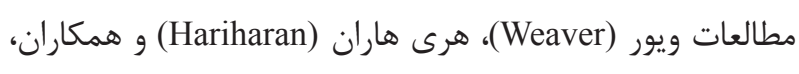

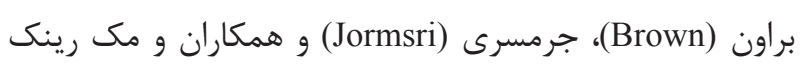
حاكى از وجود نقاط ضعفى در عملكرد يرستاران در (McCrink)

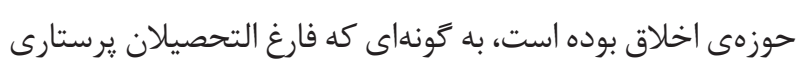

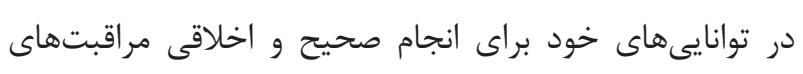

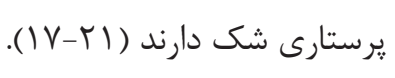

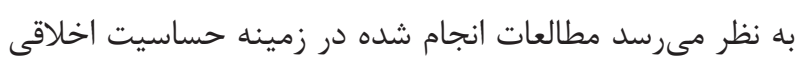

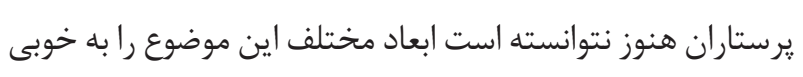

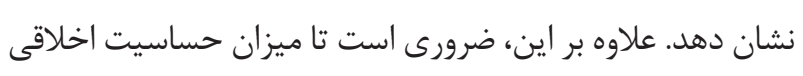

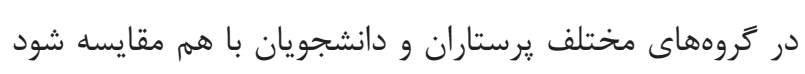
تا اثرات شرايط مختلف بر اين موضوع مورد بررسى قرار كيرد.

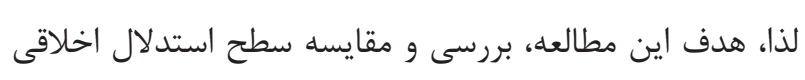
دانشجويان و يرستاران شاغل با يكديخر است.

\section{مواد و روشها}

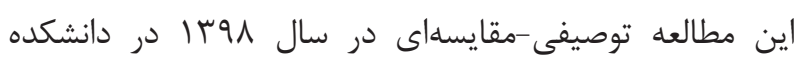

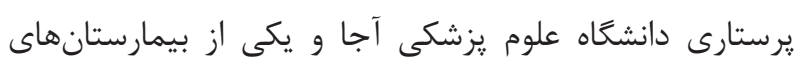

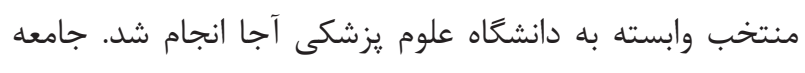

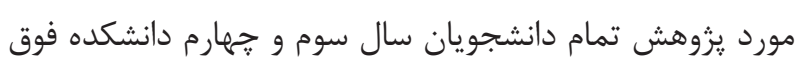

موضوعى است كه به استدلال اخلاقى افراد در آن موقعيت خاص بستخى دارد (ه). لارنس كلبرى (Lawrence Kohlberg) يكى از مهرمترين نظريه يردازانى است كه درباره رشد اخلاقى در انسانها مطالعه

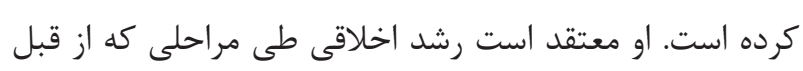

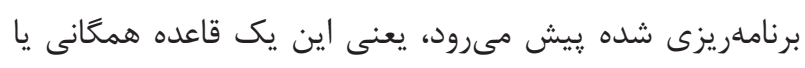

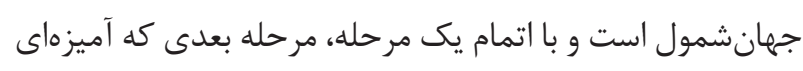

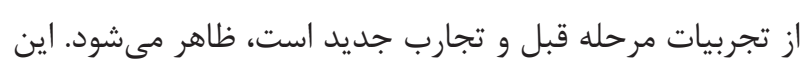

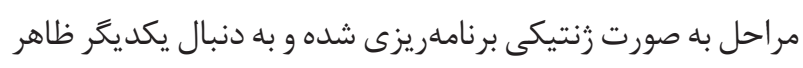

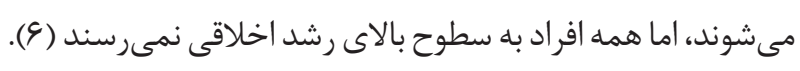

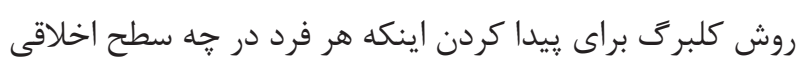

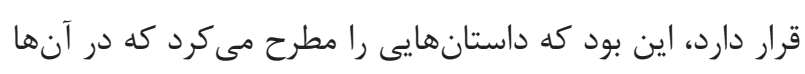

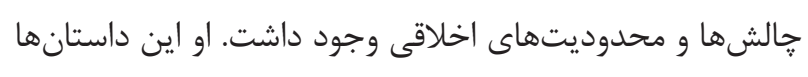

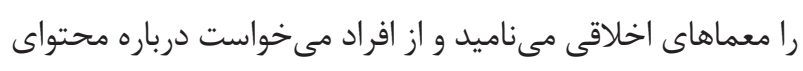
داستانها و آنجه قهرمانان داستان انجام دادهاند، قضاوت كنيند. سطح قضاوت اخلاقى به نوع استدلالى كه فرد به كار مىبرد

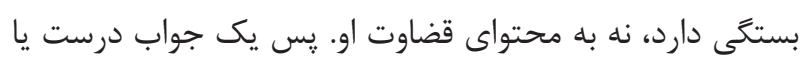

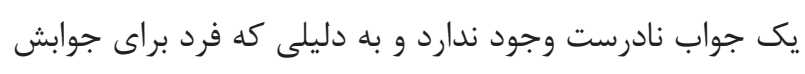

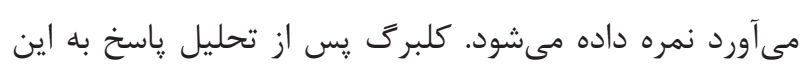

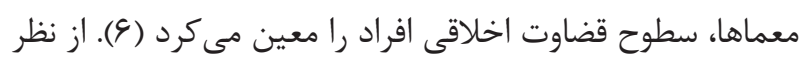
او، افراد در سه سطح اخلاقى ييشعرفى (Preconventional)، عرفى (Conventional) و و يسعرفى (Postconventional) قرار مى گيرند. سطح اول كه اخلاق ييشعرفى است شامل مراحل

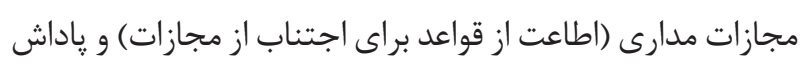

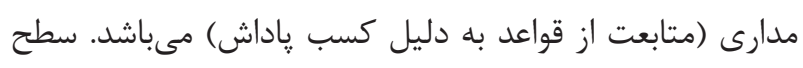

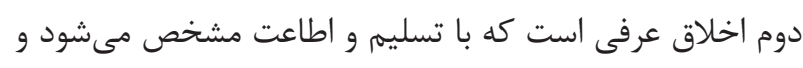

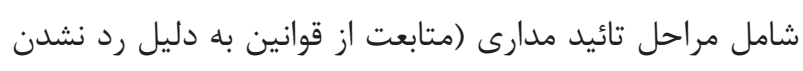
از جانب ديخران) و اقتدارمدارى (تبعيت از قوانين براى آنكه از مداز طرف منابع قدرت محكوم نشود و از بابت انجام ندادن وظيفه

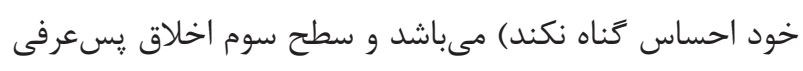

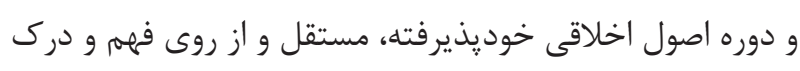
است كه خود به دو مرحلهى ييمان مدارى (اعمال فرد مطابق با

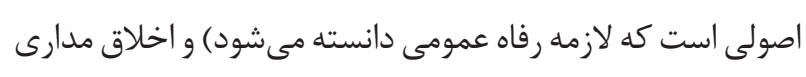

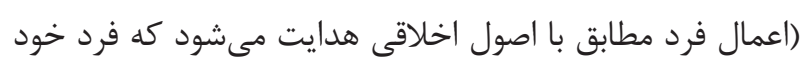


مىشود تا به ترتيب اولويت اين گزينهها را مرتب نمايد. لازم به

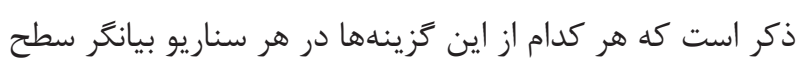

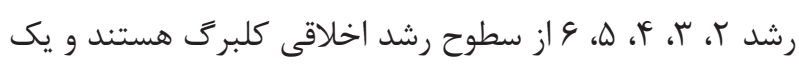

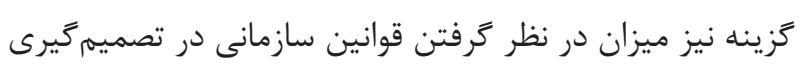
را بر استفى مىنمايد. با استفاده از اين يرسشنامه، دو شاخص مهمهم براى هر آزمودنى

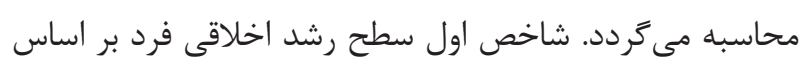

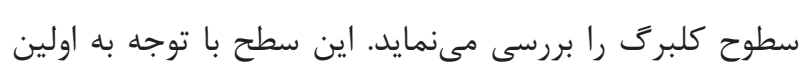
انتخاب آزمودنىها در هر سناريو تعيين مىشود. (با در نظر كرفتين اينكه هر ززينه نشاندهنده يكى از سطوح است). شاخص بعدى آنى

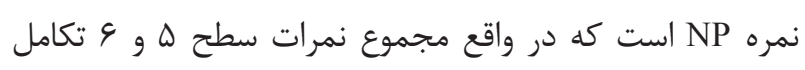

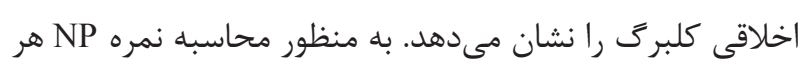

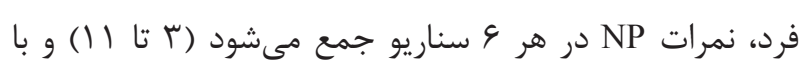

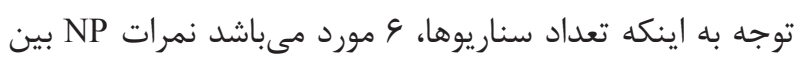

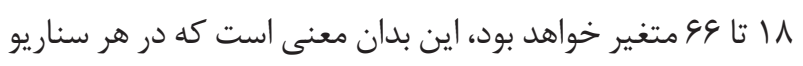

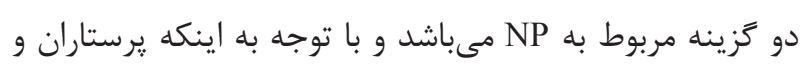

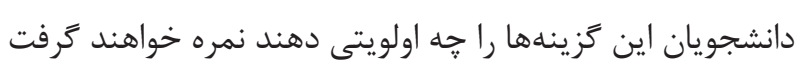

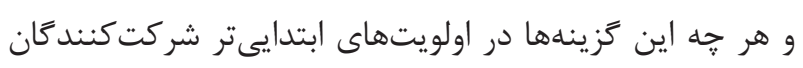

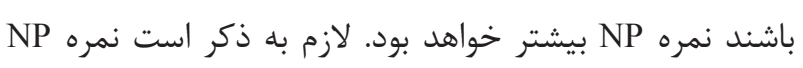

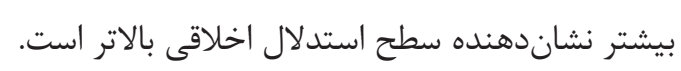

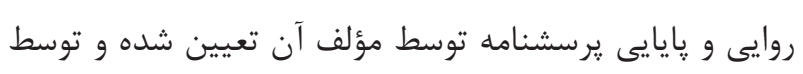

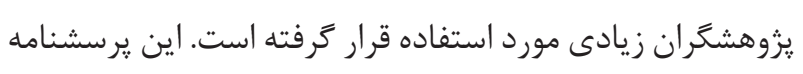

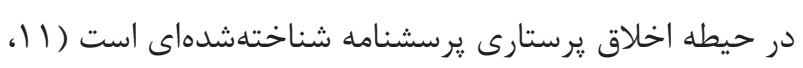

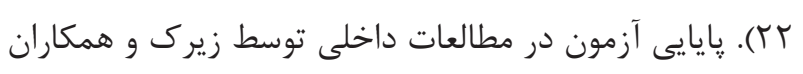

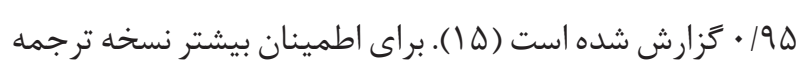

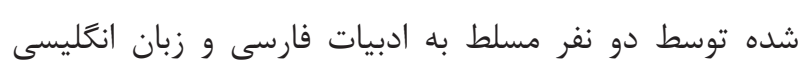

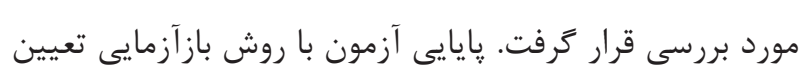
شد. به اين منظور، يرسشنامه در دو نوبت به لـ لـ دانشجو ارائه

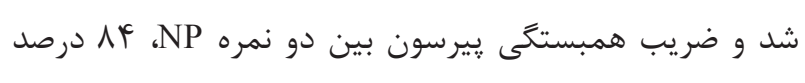
محاسبه گرديد. براى رعايت ملاحظات اخلاقى، در آغاز مطالعه در خصوص اهداف يروهش و محر مانه بودن اطلاعات شركت كنند كان توضيحات لازم به صورت شفاهى و كتبى در ابتداى يرسشنامه داده شد و رضايت شفاهى آنان براى شركت در يزوهش كسب ترديد.

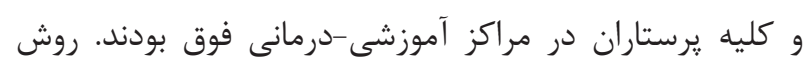

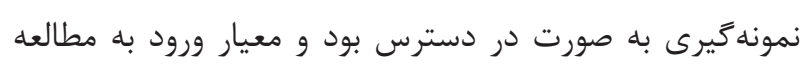

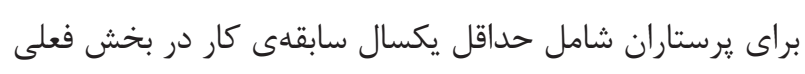

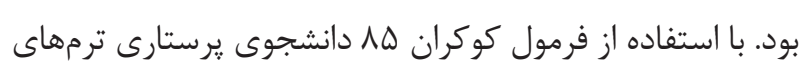

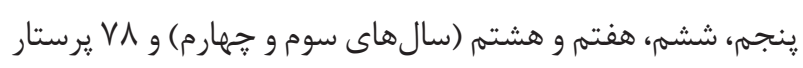
بالينى در اين يزوهش شركت نمودند.

$$
n=\frac{\frac{Z^{r} p q}{d^{r}}}{1+\frac{1}{N}\left(\frac{Z^{r} p q}{d^{r}}-1\right)}
$$

$Z=1 / 94, P=\cdot / \cdot \Delta, q=\cdot / \Delta, d=\cdot / \cdot \Delta, N=9 \Lambda \quad$ (برستاران) $Z=1 / 94, P=\cdot / \cdot \Delta, q=\cdot / \Delta, d=\cdot / \cdot \Delta, N=1$ • 9 (دانشجويان يرستارى)

جهت جمع آورى دادهها از يرسشنامه استفاده شد. اين برسشنامه شامل دو قسمت بود. قسمت اول، برخى مشخصات دانشجويان

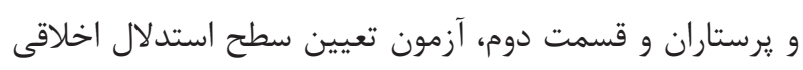
شركت كنند كان بود. براى اندازمخيرى سطح استدلال اخلاقى از آزمون لامعضلات

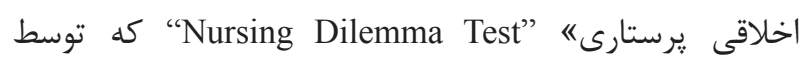
Chrishm استفاده شد. اين يرسشنامه بر مبناى نظريه كلبرى (Kohlberg)

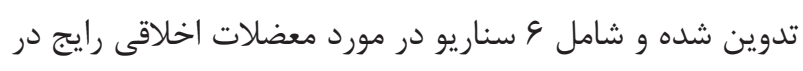
حيطه مراقبتهاى يرستارى است. اين معضلات شامل نوزاد مبتلا به نقص عضو، تجويز اجبارى دارو، درخواست بيمار براى يايان

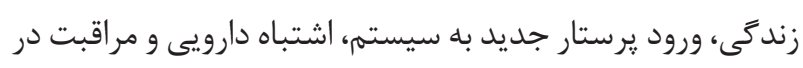

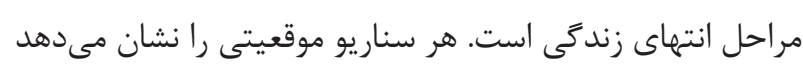

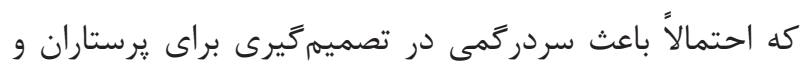

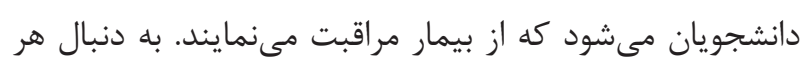

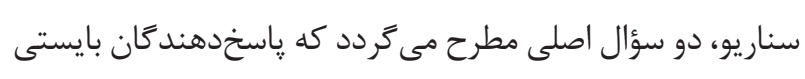

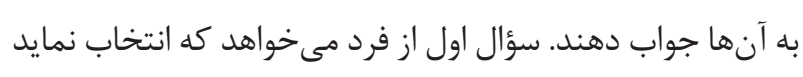

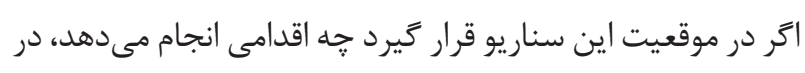

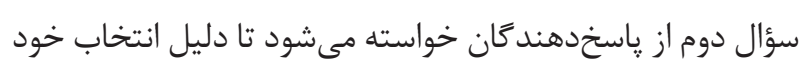

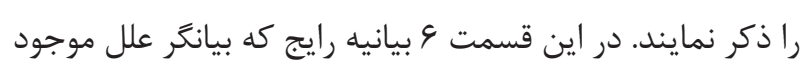

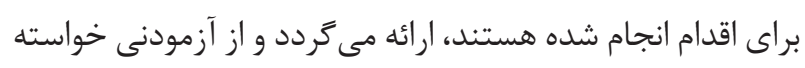


عدم اطمينان در تصميمَيرى اخلاقى است در يرستاران بيشتر از دانشجويان است. نتايج آزمون تى با نمونهاى مستقل حانئ ساكى از آن است كه بين

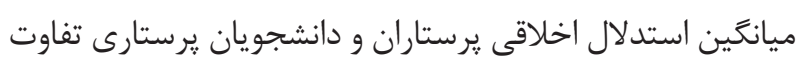

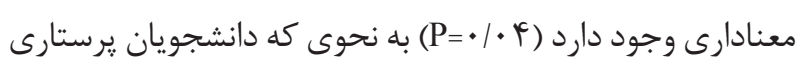

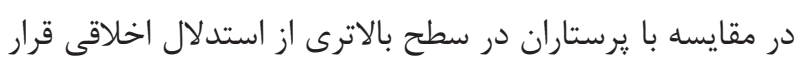

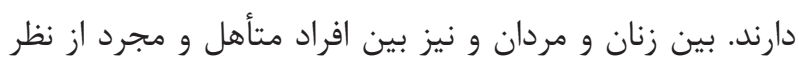

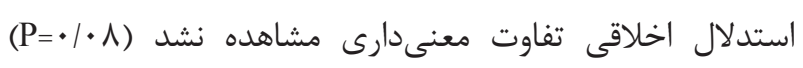

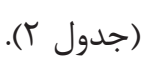

\section{بحث و نتيجه}

هدف اين مطالعه، مقايسه سطح استدلال اخلاقى يرستاران و و بنديرى

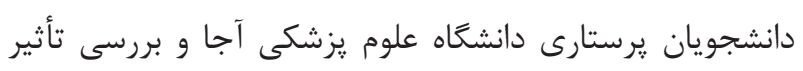
برخى مشخصات فردى بر سطح استدلال اخلاقى آنان بود. نتايج
يافتنه ها

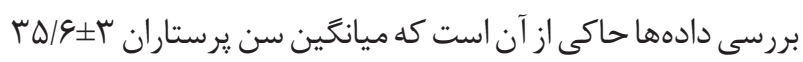

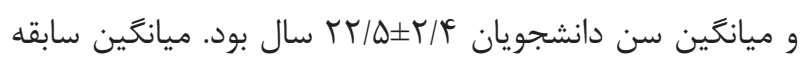
كار يرستاران 11/199 سال است كه كمترين سابقه كار يك سال و بيشترين آن TV سال است. از مجموع دانشجويان يرستارى،

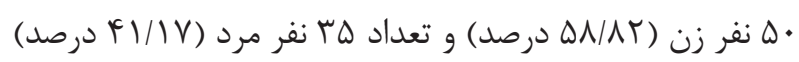
و از مجموع يرستاران عاع نفر زن (س/ه

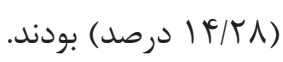
نتايج نشان داد كه ميانگين نمره استدلال اخلاقى (NP) دانشجويان

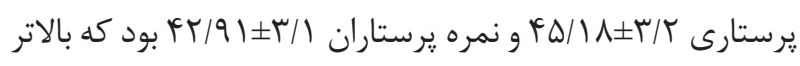
از متوسط نمر0ى يرسشنامه (جهل و دو) مىباشد. جدول شماره ا، نظرات يرستاران و دانشجويان يرستارى در آزمون معضل اخلاقى را نشان مىدهد. نتايج جدول حاكى از آن است كه در اكثر موارد گزينه "يرستار نمى تواند تصميم بخيرده كه نشان از

جدول ا- ديدكاه دانشجويان يرستارى و يرستاران در خصوص سناريوهاى آزمون NDT

\begin{tabular}{|c|c|c|c|}
\hline \multicolumn{2}{|c|}{ 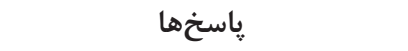 } & \multirow{3}{*}{ ياسخهاى موجود براى هر سناريو } & \multirow{3}{*}{ سناريوها } \\
\hline & & & \\
\hline تعداد (درصد) & تعداد (درصد) & & \\
\hline $1 T(Y q / 1 \Delta)$ & $q(1 / / \Delta r)$ & نمىتوان در موقعيت مذكور تصميم گرفت & \multirow{3}{*}{ وزاد با آنومالىهاى شديد } \\
\hline$r q(r y / l)$ & $r r(r q / 4 \wedge)$ & بايد نوزاد را احياء كرد & \\
\hline$F T(\Delta \cdot \mid \Delta \Lambda)$ & fG $(\Delta \wedge / 9 \vee)$ & نبايد نوزاد را احياء كرد & \\
\hline $1 \Gamma(Y q / 1 \Delta)$ & $10(19 / 4 \pi)$ & نمىتوان در موقعيت مذكور تصميم گرفت & \multirow{3}{*}{ 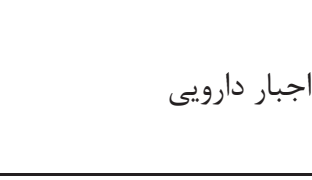 } \\
\hline$F V(\Delta \Delta / r q)$ & $\uparrow \Delta(\Delta V / 9 \varphi)$ & نبايد دارو را به زور تزريق كرد & \\
\hline$r \Delta(Y q / F))$ & $\ln (Y \mathrm{r} / \cdot \mathrm{V})$ & بايد دارو را به زور تزريق كرد & \\
\hline $1 T(|F /| 1)$ & $1 \Gamma(19 \mid 99)$ & نمىتوان در موقعيت مذكور تصميم گرفت & \multirow{3}{*}{ تقاضاى بالغين براى مردان } \\
\hline rq (re/ll) & $r)(r q / Y \wedge)$ & بايد به برقرارى تنفس بيمار كمك كرد & \\
\hline$F F(D \mid / V G)$ & $\operatorname{Ff}(\Delta G / F \mid)$ & نبايد به برقرارى تنفس بيمار كمك كرد & \\
\hline$V(\Lambda / Y \mu)$ & $V(\Lambda / 9 \vee)$ & نمىتوان در موقعيت مذكور تصميم كرفت & \multirow{3}{*}{ شاسازى يرستار جديد } \\
\hline GV (VA/Ar) & $\operatorname{sf}(\Lambda T / \cdot \Delta)$ & بايد زمان براى آشناسازى يرستار جديد اختصاص داد & \\
\hline $\left.11(1 T / 9)^{\mathrm{f}}\right)$ & $\vee(\Lambda / 9 \vee)$ & نبايد زمان براى آشناسازى يرستار جديد اختصاص داد & \\
\hline$\| r(|Y /| 1)$ & $r \cdot(Y \Delta / G Y)$ & نمىتوان در موقعيت مذكور تصميم گرفت & \multirow{3}{*}{ اشتباه دارويى } \\
\hline$\Delta V(\Phi V / \cdot \Delta)$ & $\forall \wedge(\varepsilon / / \Delta r)$ & بايد اشتباه دارويى را ززارش نمود & \\
\hline $19(1 \mathrm{~N} / \mathrm{Ar})$ & $1 \cdot(I T / A T)$ & نبايد اشتباه دارويى را ززارش نمود & \\
\hline IV $(Y \cdot)$ & 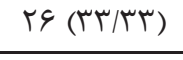 & نمىتوان در موقعيت مذكور تصميم گرفت & \multirow{3}{*}{ بالغين با بيمارى شديد } \\
\hline$F \cdot(F V / \cdot \Delta)$ & $19(r \cdot 101)$ & بايد به سؤالات بيمار در مورد سلامتى پاسخ داد & \\
\hline$r \Lambda(r T / q r)$ & rG $(\uparrow q / \mid \omega)$ & نبايد به سؤالات بيمار در مورد سلامتى پاسخ داد & \\
\hline
\end{tabular}


جدول r- ميانگين نمرات استدلال اخلاقى بر اساس متغيّر هاى مورد بر رسى

\begin{tabular}{|c|c|c|c|}
\hline سطح معنى دارى & ميانكَين استدلال اخلاقى & متغير & \\
\hline \multirow{2}{*}{$\cdot / \cdot F$} & $F \Delta / / \Lambda \pm T / Y$ & دانشجويان يرستارى & \multirow{2}{*}{ كرومها } \\
\hline & $F r / q 1 \pm T / 1$ & يرستاران & \\
\hline \multirow{2}{*}{$\cdot 1 \cdot 1$} & Fr/Tl & مجرد & \multirow{2}{*}{ 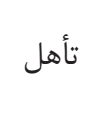 } \\
\hline & $F r / \cdot F$ & متأهل & \\
\hline \multirow{2}{*}{$\cdot / \cdot \Lambda$} & FT/AT & 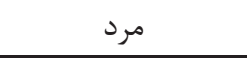 & \multirow{2}{*}{ جنس } \\
\hline & Fr/GA & زن & \\
\hline
\end{tabular}

حاكم بر محيط دانشكدها، نوع آموزش در دانشكدها، اهميت

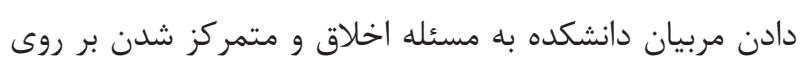

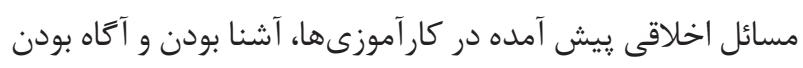

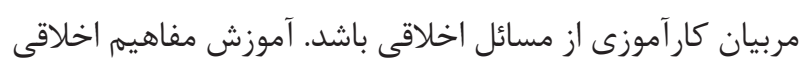

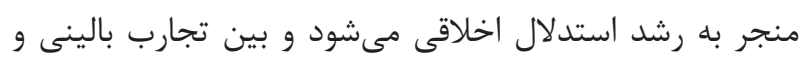

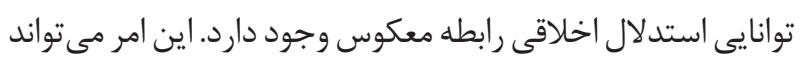
ناشى از فاصله ترفتن از آموزش هاى اخلاقى و عادى شدن مسن مسائل

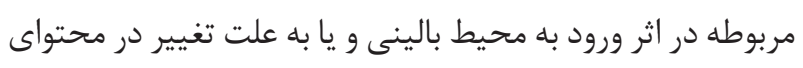

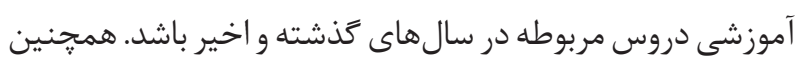
جو حاكم بر سازمان محل خدمت يرستاران، شيوه مديريتى مديران

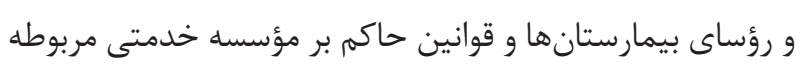
و پايبندى افراد به ارزشهاى مذهبى از جمله عوامل تأثير حذار بر استدلال اخلاقى يرستاران مى باشد.

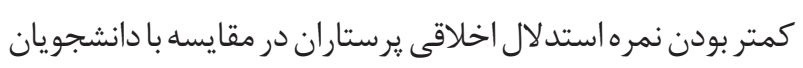
يرستارى زنغ خطرى براى مديران يرستارى است كه نيازمند

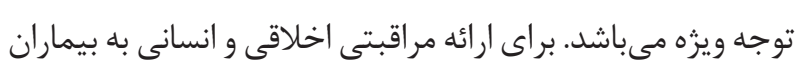

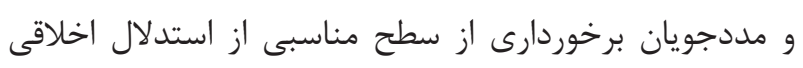

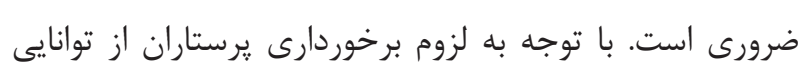

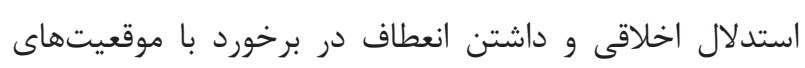

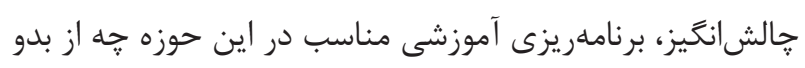

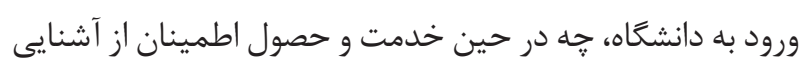
يرستاران و دانشجويان با كدهاى اخلاقى و همكارى هر خه به بيشتر

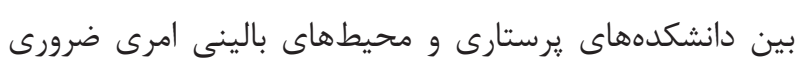

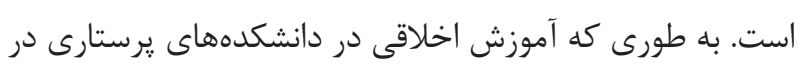

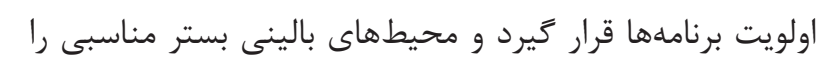
براى ارائهى مهارتهاى آموخته شده فراهم آورند.
اين مطالعه نشان داد كه سطح كلى استدلال اخلاقى در دانشجويان

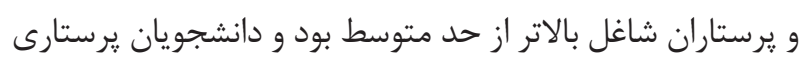
در سطح بالاترى از استدلال اخلاقى در مقايسه با برستاران شاغل بانل

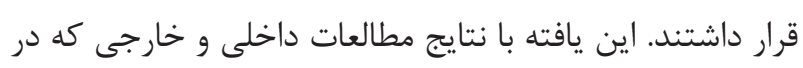

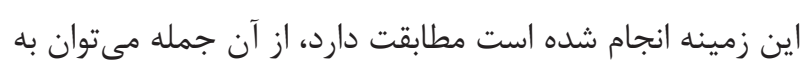

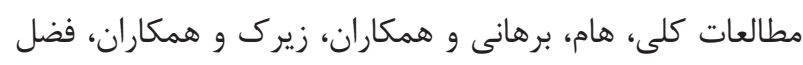

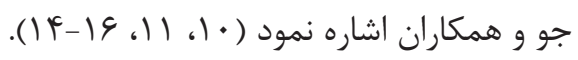

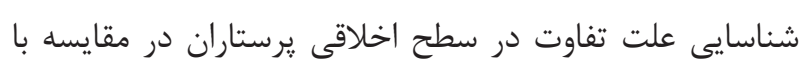
دانشجويان نيازمند بررسىهاى بيشتر و در نظر كرفتن عوامل

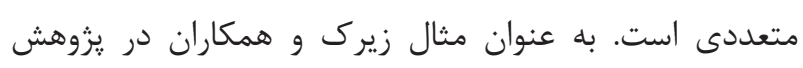

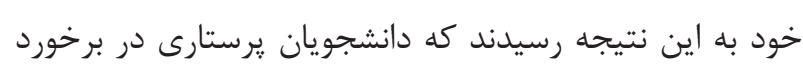

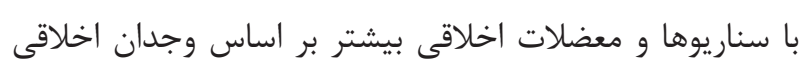

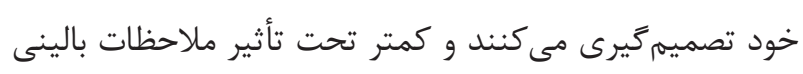

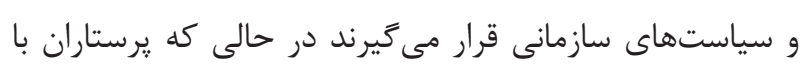

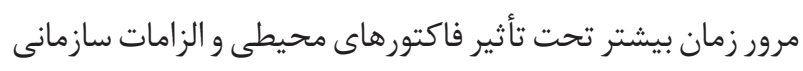

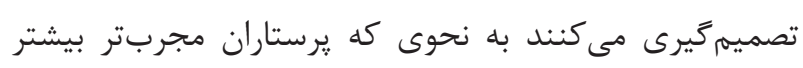

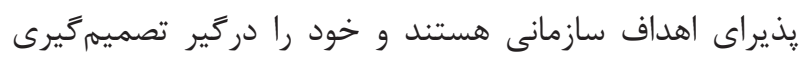

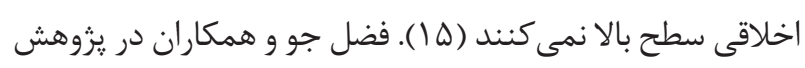

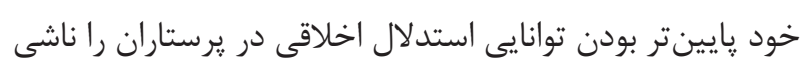

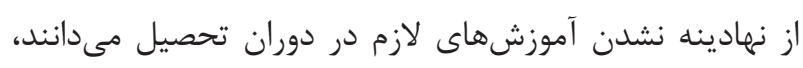

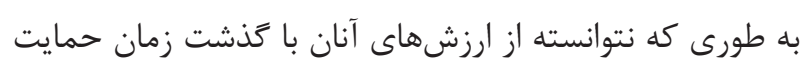

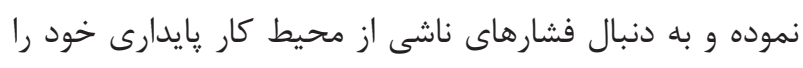

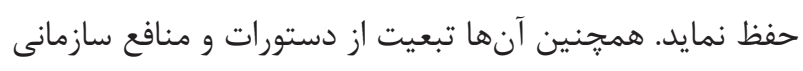
به دليل ترس از دست دادن موقعيت شغلى خود را يكى ديخر از

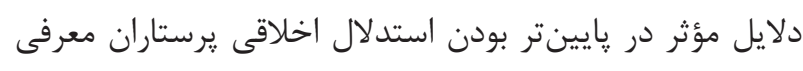

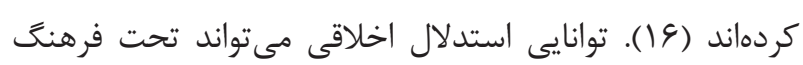




$$
\begin{aligned}
& \text { تشكر و قدردانى } \\
& \text { يزوهشَّران بر خود لازم مىدانند از كليه يرستاران و دانشجويان } \\
& \text { شركت كننده در اين تحقيق و كليه مسئولان مربوطه، تشكر و }
\end{aligned}
$$

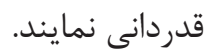

$$
\begin{aligned}
& \text { تضاد منافع } \\
& \text { بدين وسيله نويسندگان تصريح مىنمايند كه هيج گونه تضاد } \\
& \text { منافعى در خصوص يزوهش حاضر وجود ندارد. }
\end{aligned}
$$

\section{References}

1- Aitamam E, Leino-Kilpi H, Puukka P, Suhonen R. Ethical problems in nursing management: The role of the codes of ethics. Nurse Ethics. 2010; 17(4): 469-82. DOI: 10.1177/0969733010364896 PMID: 20610580

2- Karimi Noghondar M, Tavakoli N, Borhani F, Mohsenpour M. Ethical sensitivity: A comparision between the nursing students and nurses of Azad University. Ijme. 2016; 8 (5):69-76. (Persian)

3- Edwards SD. Nursing Ethics: A Principle-based Approach, 2nded. London: McMillan; 2009, p.8-10. DOI: 10.1177/09697330100170041202

4- Butts JB, Rich. Nurs Ethics: Across the curriculum and into Practice, 2nd edition. London: Jones \& Bartlett learning; 2005, p.17, 55. DOI: $10.1177 / 09697330080150041602$

5- Fagan JA. Ethical changes in the Nursing student [MSc dissertation]. California (USA). California State University; 2006.

6- Colby A, Kohlberg L, Gibbs J, Lieberman M, Fischer, K, Salttstein H. A longitudinal study of moral judgment. Monographs of the society for research in child development, 1983; 48(1-2), 48-124. DOI: $10.2307 / 1165935$

7- Kohlberg, L. Essays on moral development: Volume I. The philosophy of moral development. San Francisco: Harper \& Row; 1981. DOI: $10.1017 /$ S0360966900024452

8- Mayberry M. Ethical decision making: A response of hospital nurses, Nurs Adm Q; 1986; 10(3): 75-81. DOI: 10.1097/00006216198601030-00006 PMID: 3634953

9- Auvinen J, Suominen T, Leino-Kilpi H, et al. The development of moral judgment during nursing education in Finland. Nurse Education Today. 2004; 24(7): 538-46. DOI: 10.1016/j. nedt.2004.07.005 PMID: 15465169

10- Kelly, B. Preserving moral integrity: A follow up study with new graduate nurses. Journal of Advanced Nursing; 1998; 28(5): 113445. DOI: 10.1046/j.1365-2648.1998.00810.x PMID: 9840887

11- Ham KL. A Comparison of ethical reasoning abilities of senior baccalaureate nursing students and experienced nurses [Ph.D. dissertation]. Tennessee. The University of Memphis; 2002.

12- Kudzma, EAC. Moral reasoning of nurses in the work setting
اين مطالعه داراى محدوديتهايى است كه هنگًام كاربرد نتايج آن بايد مدنظر قرار گيرد. در اين مطالعه تنها يرستاران شاغل در يكى از بيمارستانهاى منتخب وابسته به دانشعاه علوم يزشكى آجا شركت نمودند، همجنين دادههاى دانشجويان و يرستاران با روش خود گزارش دهى تكميل شد؛ بنابراين پيشنههاد مىشود مطالعات مشابهى در ساير مراكز درمانى انجام گردد تا با شناسايى دقيقتر عوامل بالينى تأثير گذار در تصميمَيرىهاى اخلاقى و بهسازى محيطهاى بالينى، :يرستاران را در استدلال اخلاقى بالا و اتخاذ تصميمات اخلاقى حمايت كرد.

(dissertation) Massachusetts, Boston University School of Nursing; 1980.

13- Negarande R, Ghobadi S.The survey of knowledge and attitude of nurses and midwives of Zanjan hospitals about ethical issues. Journal of Advances in Medical and Biomedical Research. 2001; 9 (36): 55-59. (persian)

14- Borhani F, Abbaszadeh A, Kohan M, Fazel M A. Nurses and nursing student's ethical reasoning in facing with dilemmas: a comparative study. Medical Ethics and History of Medicine. 2010; 3 (4): 71-81 (Persian)

15- Zirak M, Mogadasian S, Abdullah-Zadeh F, Rahmani A. Comparison of ethical reasoning in nursing students and nurses in Tabriz University of medical science. Advances in Nursing and Midwifery.2011; 22 (77):1-9 (Persian)

16- Fazljoo SE, Abbaszadeh A, Loghmani L. Comparision of moral reasoning of nursing students and nurses in Meybod city in facing with Dilemmas. Medical Ethics Journal. 2018; 12 (43): 1-9 (Persian)

17- Weaver k. Ethical sensivity: state of knowledge and needs for further research. Nurse Ethics 2007; 14(2):215-23. DOI: 10.1177/0969733007073694 PMID: 17425144

18- Hariharan S, Jonnalagadda R, Walrond E, Moseley H. Knowledge, attitudes and practice of healthcare ethics and law among doctors and nurses in Barbados. BMC Med Ethics. 2006; 7: 7. DOI: 10.1186/1472-6939-7-7 PMID: 16764719 PMCID: PMC1524795

19- Brown CJ. Self-renewal in nursing leadership: The lived experience of caring for self. J Holist Nurse 2009; 27(2); 75-84. DOI: 10.1177/0898010108330802 PMID: 19182266

20- Jormsri P, Kunavicticul W, Ketefian Sh, Chaowalit A. Moral competence in nursing practice. Nurse Ethics. 2005; 12(6): 58294. DOI: 10.1191/0969733005ne828oa PMID: 16312087

21- McCrink A. Nursing student attitude towards academic misconduct, the code of ethics for nurses and their commitment to the ethic of caring [Ph.D. Dissertation]. New York: Dowling College; 2008.

22- Crishm P. Measuring moral judgment in nursing dilemmas. Nursing Res 1981; 30(2):104-10. DOI: 10.1097/00006199198103000-00012 PMID: 6907863 